\title{
URBANIZATION, ENVIRONMENTAL PLANNING AND MANAGEMENT: A CHALLENGE FOR JAMAICA
}

\author{
Leiska J. Powell ${ }^{1}$ \\ Faculty of Engineering \\ UNIVERSITY OF THE WEST INDIES, TRINIDAD
}

\begin{abstract}
The rapid pace of urbanization has presented numerous challenges for developing countries such as Jamaica. The effects of urbanization coupled with poor environmental and development practices have exerted tremendous pressure on the country's fragile and limited natural resources. This issue is exacerbated by poverty, poor urban planning and management and lack of enforcement of existing land use regulations. The purpose of this paper is to critically examine the challenges in reversing negative environmental trends and practices which is increasing the vulnerability of the population, economy, infrastructure and other vulnerable elements of the society to the devastating impacts of natural hazards. The growing threats from hurricanes and tropical storms has have occurred over the last 10 years have highlighted the need for more sustainable development. The report concludes with a number of recommendations that are critical to address the never ending cycle of environmental degradation.
\end{abstract}

Keywords: Urbanization, environmental planning, management, Jamaica

\section{INTRODUCTION}

Urbanization (the process through which cities and towns develop and grow) today is extraordinary with the world undergoing the largest wave of urban growth in history. The United Nations Population Fund 2008, highlighted that for the first time, more than half of the world's population will be living in towns and cities. They further highlight that by 2030 this number will swell to almost 5 billion, with urban growth concentrated in Africa and Asia. In the case of Small Island Developing States (SIDS), the United Nations Human Settlement Programme noted that of the 52 million people in SIDS, 30 million (or 58 percent) live in urban areas, with Caribbean SIDS being the most

${ }^{1}$ MS.c Student, Planning and Development, Faculty of Engineering, University of the West Indies, St. Augustine, Trinidad (Email: leiska_powell@hotmail.com) 
urbanized. Urban areas in Caribbean SIDS are located on the coast of these islands, and as noted by Rakodi and Treloar (1997), natural and coastal resources are always under threat from rapid development and population increase within the coastal zone. This continued growth of urban areas is attributed to the fact that cities are often seen as the engine for economic growth, however, governments' abilities to manage the unprecedented wave of urbanization has proven to be a challenge for many countries.

Leitmann et al (1992), pointed out that the immediate and most critical environmental problems facing Third World cities (including SIDS) encompass what is referred to as the 'brown agenda'- lack of safe water, inadequate waste management and pollution control, accidents linked to congestion and overcrowding, occupation and degradation of sensitive lands and the interrelations between these problems. In the case of Jamaica, which is the focus of this paper, urbanization, land use planning and environmental management continues to be a major challenge as population growth, coupled with agricultural, tourism, commercial and industrial expansion, has resulted in increase competition for local resources. This competition has exerted significant pressure on the country's fragile ecosystems. Added to this pressure, land use planning as an activity has been marginalized as there is little or no adherence and compliance to planning standards by developers, the lack of enforcement of said regulations and the use of outdated Development Orders (instruments that regulate the development of land), have gravely impeded attempts of achieving sustainable development.

This paper first presents a background of the case study of Jamaica and then an overview of urbanization trends in the country. This is followed by an analysis of the environmental problems and issues stemming from the impact of urbanization on land use and natural resource management. The last section of the paper discusses the main challenges plaguing environmental planning and management and also presents a number of recommendations which are germane to achieving sustainable development of land resources which meets people's needs and demands.

The empirical data for the case study comes from direct observation in the city of Kingston and Montego Bay, the two largest urban centres in Jamaica and from interviews with land use planners and other stakeholders involved in the planning process. A plethora of literature was reviewed to ascertain urbanization trends and practices, the planning and legislative framework geared towards the conservation and sustainable use of resources as well as the main challenges affecting effective environmental planning and management in Jamaica. The information collected was analyzed and is summarized in this 
paper. Additionally, to aid in the analysis and discussion, this paper is guided by three (3) research questions:

1. What are the impacts of the process of urbanization on land use and natural resources?

2. What are the challenges hindering effective environmental planning and management?

3. What mix of strategies/measures is essential to arrest environmental degradation in order to achieve sustainable urbanization?

\section{BACKGROUND}

Jamaica is the third largest island in the Caribbean with a landmass of 10,991 square kilometres. Approximately two-thirds of the land resources consist of a central range of mountains and hills, surrounded by a narrow coastal plain.

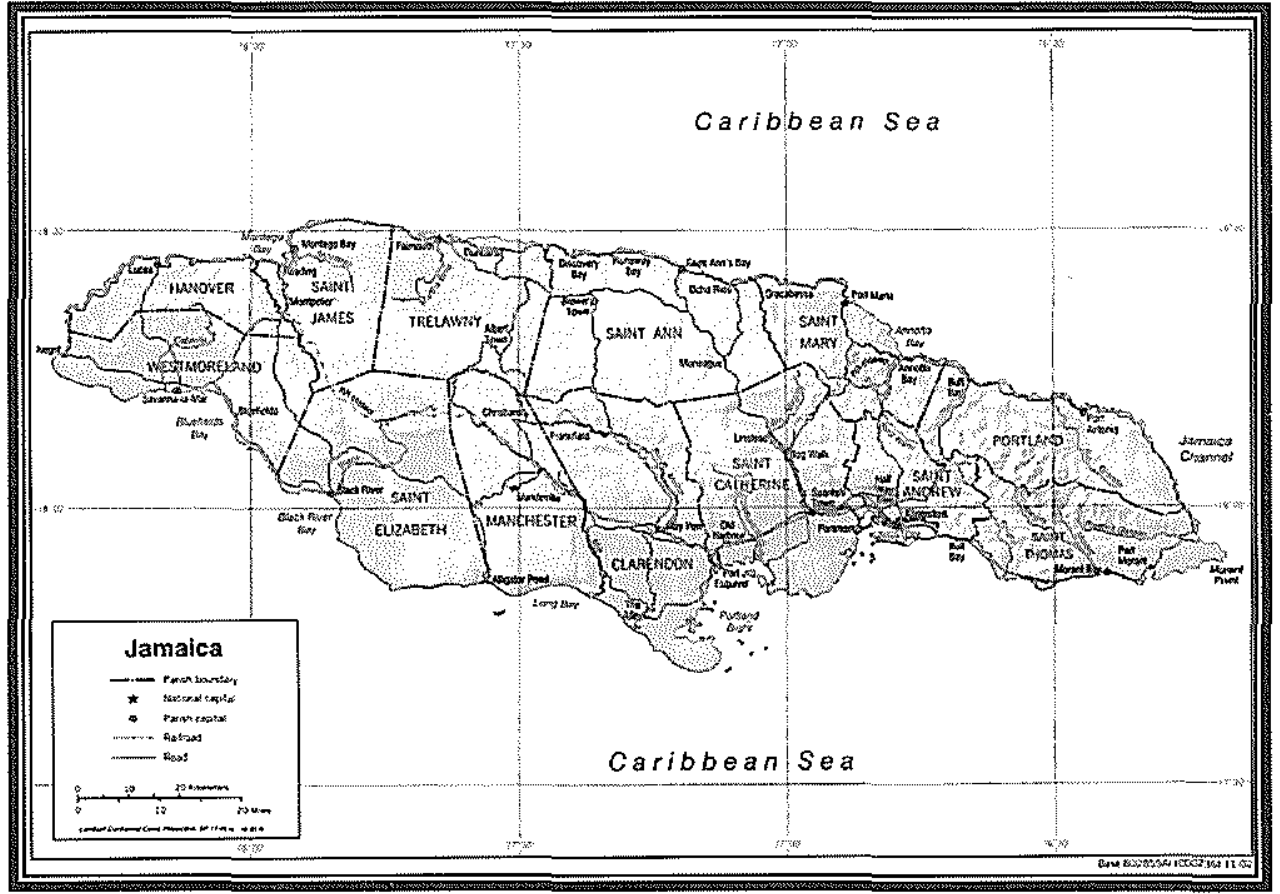

Figure 1: Spatial Context of Jamaica

Most major towns and cities are situated on the coast. Kingston, the country's capital, situated on the south-eastern coastline (Figure 1) is the main 
urban centre and is the major hub for transport linkages, service type industries and public and private sector services, which has a direct sphere of influence over all the parishes. St. Andrew, though not the main service centre, has grown as an important support for public and private sector services and also the main residential urban areas.

Montego Bay is the second largest urban centre in Jamaica, and is also the second capital of Jamaica, providing similar services to Kingston, but to the western and north western end of the island (See Figure 1).

\section{Urbanization Trends}

The current population of Jamaica is estimated at 2.6 million with some 52 percent living in urban areas. According to the Statistical Institute of Jamaica, growing at an annual rate of 1.42 per cent between 1991 and 2001, the urban population moved from $1,192,000$ to $1,354,900$. This growth however, was only for four parishes; Kingston, St. Andrew, St. Catherine and St. James that the urban population was in excess of $50 \%$ of the total population of the parish. Furthermore, the population for the Kingston Metropolitan Area (KMA) alone in 2001 stood at 579,137 , representing 88 per cent of the total population of Kingston and St. Andrew combined and 22.2 per cent of the country's population.

Notwithstanding that, the parish of St. Catherine has been noted as the fastest growing peripheral area growing 26.3 per cent between 1991 and 2001. The expansion of St. Catherine has been described by Portes et al (1993), as that of "the city of Kingston has stretched out a hungry arm into the adjacent parish of St. Catherine, reaching to embrace new residential areas in its overspill of population in the area know as Portmore". Wade and Webber (2002) in their research found that Portmore, the satellite community of Kingston has experienced annual growth above 5 per cent.

Empirical data shows that since 1985 urbanization growth in Jamaica has been increasing steadily, a trend that is expected to continue to increase as shown in Figure 2 below. Moreover, it is estimated that, by 2020 , the national population will reach 3 million, $60 \%$ of which are expected to reside in urban areas (United Nations Demographic Yearbook, 2003). Such data indicate a strong wave of urbanization, with most of the population pressures being exerted on the natural resources and also in the coastal zone of the country and presents a challenge. 


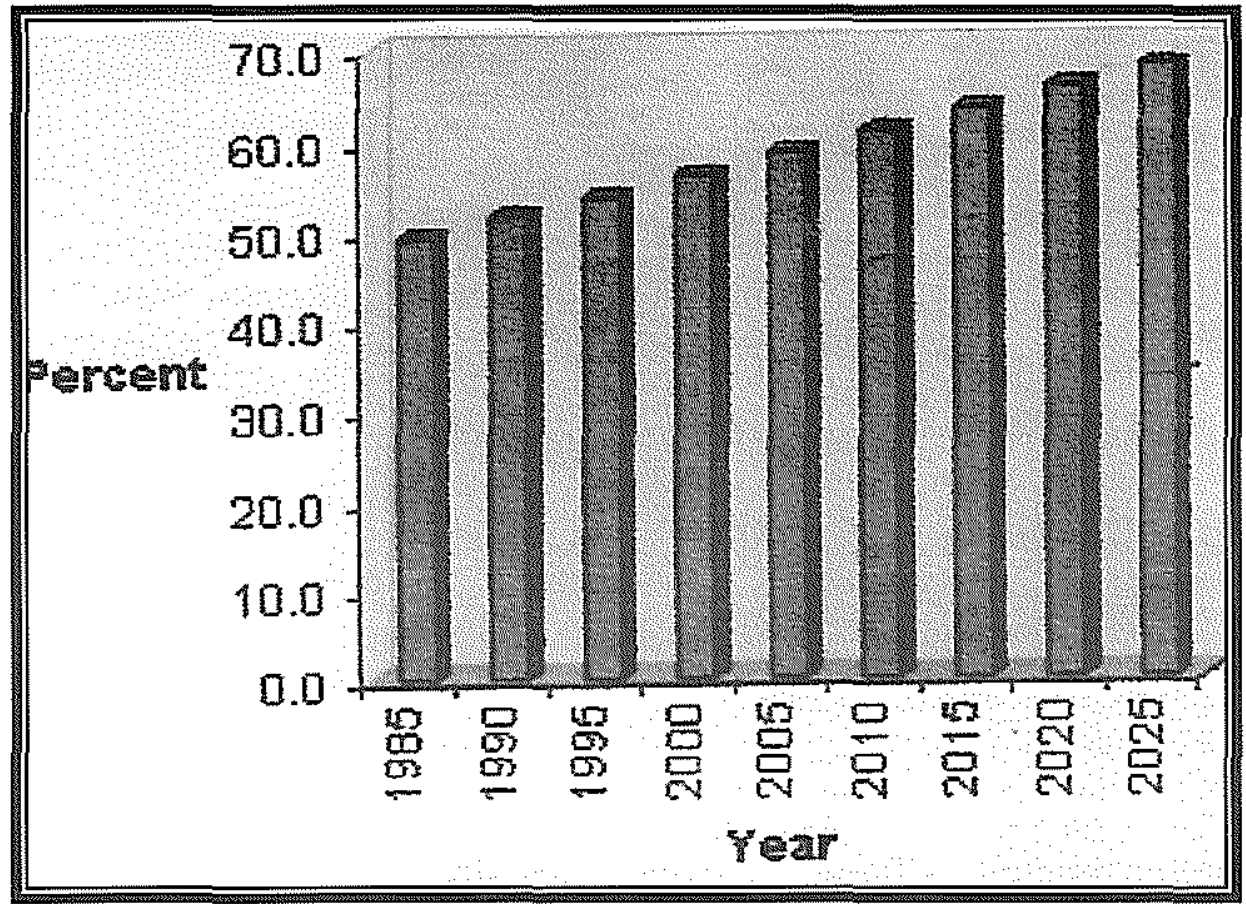

Figure 2: Urbanization Growth in Jamaica.

(Source: United Nations Demographic Yearbook, 2003)

\section{URBANIZATION AND ENVIRONMENTAL CHALLENGES}

The Jamaica National Assessment Report, 2003 highlighted that rapid urbanization has resulted in major problems such as squatting, inadequate housing and social services, inadequate infrastructure, traffic congestion and urban decay. This phenomenon is referred to as decapitalized urbanization whereby the rapid growth of the population has outpaced government's ability to provide basic services such as housing, physical infrastructure and social facilities.

One of the first signs of decapitalized urbanization in Jamaica is the proliferation of squatter settlements which has mushroomed in every urban centre in the country. The absence of a coherent urban housing plan and the disenchantment of many low income families have facilitated the growth of squatting (Tindigarukayo 2006). Moreover, the decade of 1991-2001 according to Ahmad, 2005 has witnessed "the utilization of narrow river valleys, faulted mountain fronts, and land - water interface as a preferred site for both formal and informal housing development". Many of these developments, especially 
informal development, are located on marginal lands and/or on precarious sites that are vulnerable to natural and/or man-made hazards. This is compounded by poor environmental practices which perpetuate vulnerability and is often the factor that transforms the hazard into a disaster. A recent example of this is the devastation caused by Tropical Storm Gustav, 2008 which painted a grim picture of the reality that the poor are both victims and agents of poor environmental practice. Several informal settlements built in the Hope River watershed, for example, as well as along the Macgregor Gully (artificial drainage channel) in the Kingston Metropolitan Area were swallowed by the gushing waters of Tropical Storm Gustav, as shown in Figure 3. DrakakisSmith (2000:89), rightly argued that the "consequence of so much poverty is a large and increasing number of urban residents who simply seek to survive as best as they can, seemingly oblivious of the cost of the environment". Similarly. the Red Cross (1999:19) describes this unwanted demarcation as the "social geography" of many towns and cities which .... "Reflects the vulnerability of different zones to natural hazards, often with disastrous consequences for the poor".

Tourism. though the major contributor to Jamaica's economy, is also contributing to the proliferation of squatter settlements, particularly in the resort areas, attracting a large influx of workers. As a consequence of inadequate housing and other related infrastructure to support the large influx of migrants. unplanned settlements have mushroomed in the hills and along the gullies Research has shown that nineteen (19) squatter settlements arose in Montego Bay because of hundreds of tourism workers and no housing arrangements for them. Additionally, the Government of Jamaica has embarked on a Tourism Expansion Programme in which 21,639 room stocks will be added to the current stock and it is feared that more unplanned settlements with associated environmental challenges will develop.

It should be noted, however, that it is not only the poor that is contributing to environmental degradation. The Long Mountain Housing project, for middle and upper class elites, completed in 2004, destroyed the last remaining piece of dry tropical forest this side of the world which had 10 endemic species of trees including three (3) rare ones and one (1) new species. This development threatens the Long Mountain watershed that contributes to the recharge of four wells that supply potable water to the Kingston Metropolitan Area (Neufville, 2001). The Jacks Hill Housing Development in upper St. Andrew is another example of housing development by affluent Jamaicans on steep slopes, an area that is prone to land slippages. Ahmad (2005), in his research found that the processes of rock fracturing and weathering have resulted in relatively weak bedrock, where both earthquakes 
and rainfall have triggered many landslides in the past and the process continues. The net result he argues is severe denudation of hill slopes.

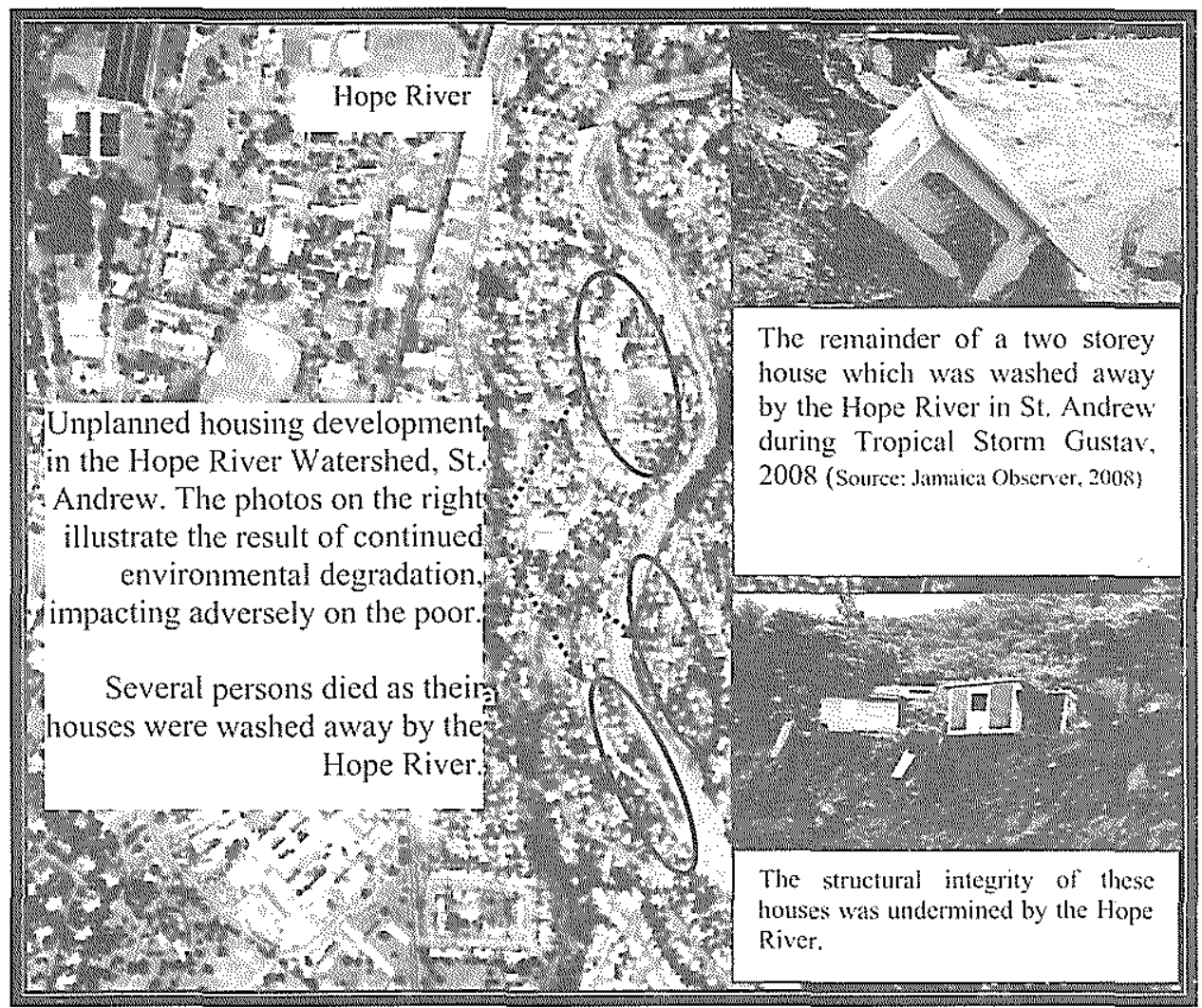

Figure 3: Devastation caused by Tropical Storm Gustav, 2008

Poor agricultural practices, quarrying, mining and the indiscriminate removal of forest cover for lumber and charcoal have also contributed to environmental degradation. Farming activities on the hillsides have long been recognized as one of the main causes of the degradation of watersheds in Jamaica. The Jamaica National Environment Action Plan (JaNEAP) noted that seventeen (17) out of twenty-six (26) watershed areas have been degraded as a result of deforestation and slash and burn farming (JaNEAP, 1999). Watershed degradation results in a reduction of freshwater resources, increased erosion and siltation of rivers, increased marine and coastal contamination and degradation adversely affecting the country's tourism industry and increased flooding. The World Bank in their research in 2000 also found that between 1990 and 1995, the annual average rate of deforestation for Jamaica was 7.2 per cent. The report further revealed that the country's annual average 
rate of deforestation was proceeding at a rate that would see the country devoid of all forest in less than 25 years. The key concern that arose, is that Jamaica being an island state, has an unusually high level of endemism and has been ranked among the world's most important islands for endemic species.

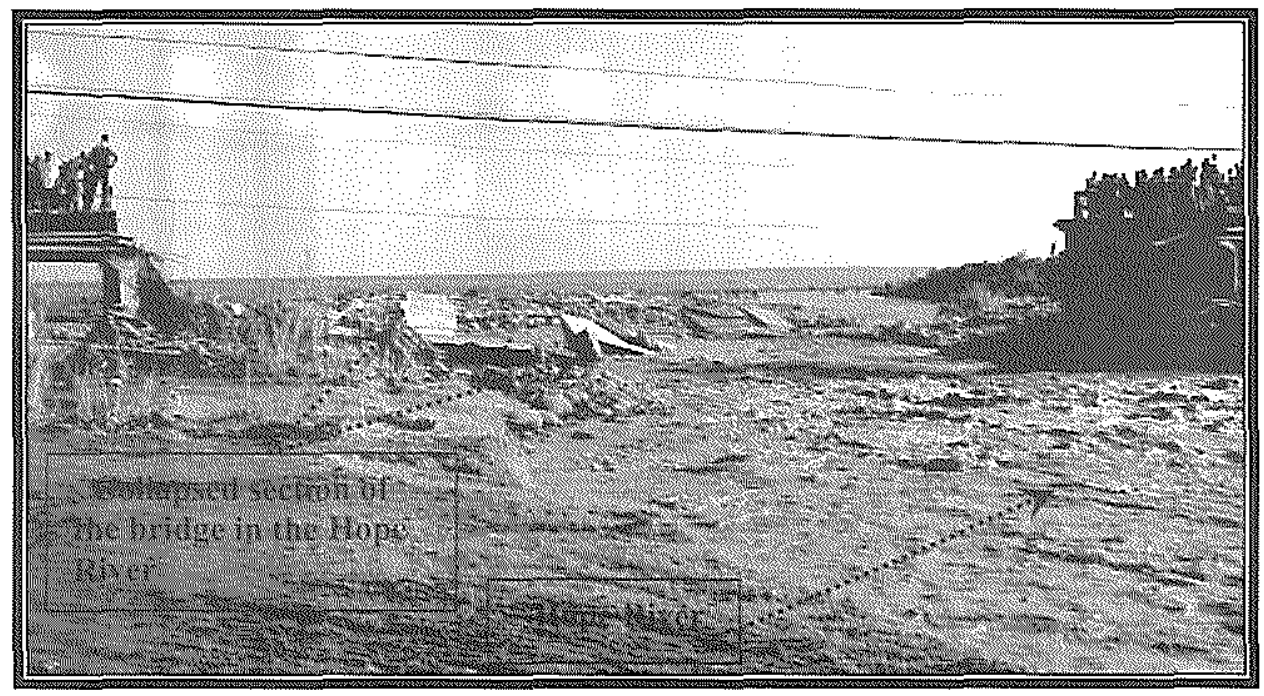

Figure 4: Collapse of Harbour View Bridge during the passage of

Tropical Storm Gustav, August, 2008.

(Source: Rodriguez ${ }^{2}, 2008$ )

Jamaica's awareness of the need for soil conservation and watershed protection dates back to the 1930s. Croucher and Swabey (1937), Wakefield (1941), and the first annual report of the Soil Conservation Division (1944) all stress these needs. Nonetheless, there does not seem to exist a clear understanding that inappropriate actions, such as deforestation, housing development and poor agricultural practices, taken within the upper regions of the watersheds can negatively impact on downstream areas including the coastal zones. Additionally, rapid urban growth and the disenchantment of low income families over the years have led to an increase in the number of unplanned settlements in the watershed areas of Kingston and Montego Bay. This has resulted in poor water quality of the rivers, severe erosion of the river banks and decreased resilience to withstand flood hazards. For example, the poor state of the Hope River Watershed transported large volumes of flood waters downstream during Tropical Storm Gustav, 2008 which contributed to the collapsed of the Harbour View Bridge (Figure 4), several landslides, flooding,

\footnotetext{
${ }^{2}$ Theresa Rodriguez, MPhil Student, Faculty of Pure and Applied Science, University of the West Indies, Mona, Jamaica.
} 
damaged roadways and loss of lives and property. Preliminary assessments by the Office of Disaster Preparedness and Emergency Management (ODPEM) indicate that an estimated JA $\$ 11$ billion in damages were sustained island-wide during the Tropical Storm, $\$ 6$ billion of which is associated with infrastructure damage.

Inadequate waste management both solid and liquid is another manifestation of the challenges of urbanization negatively impacting on the environment and the coastal zone. Approximately 70 per cent of the waste generated is collected by the National Solid Waste Management Authority primarily from the urban centres (Davis-Mattis,2005). The remaining 30 per cent of uncollected waste results in "foul odours, vermin and flies (Ministry of Local Government, 2001:3), and is either burnt or dumped in waterways and gullies which is a major source of point pollution of the coastal zone. In some of these gullies, "rubbish plies up as nearly high as the walls", and in other cases "raw sewage flows several feet high" (Jamaica Gleaner, 2003). Uncollected waste spoils the aesthetic vista of the city, a common trend in Montego Bay, the principal resort area of Jamaica. During periods of heavy rainfall, large quantities of waste from the North Gully in Montego Bay, deposits wastes into the coastal zone, creating an eye sore.

Sewage treatment and effluent quality is another concern whereby sewage plants "often do not generate effluent that meet acceptable standards for disposal", (National Environment Planning Agency (NEPA), 2001:15). The consequence of this according to NEPA is that an estimated 20 million gallons of mostly untreated sewage is discharged daily into the Kingston Harbour from several malfunctioning sewage treatment plants. The most visible symptom of this is the frequent recurrence of eutrophication which leads to depletion of oxygen, causing deterioration of water quality and a decline in biodiversity. This has drastically affected the condition of the Kingston Harbour, the seventh largest natural harbour in the world to be classified as a "Heavily Contaminated Bay" by the United Nations Office of Project Services (UNOPS), 1998. The United Nations Environment Programme (UNEP), also noted eutrophication is a growing problem in the Caribbean, threatening human health and coastal ecosystem, including coral reefs, mangroves and the fishing marine environment. These coastal ecosystems are important in mitigating the impact of natural hazards by providing protection of the coastline and beaches from hurricanes and associated storm surge which Jamaica is well acclimatized to. Figure 5 highlights the relationship between environmental degradation, natural disasters and vulnerability. Environmental degradation compounds the impacts of hazards, limits an area's ability to absorb those impacts, and reduces the 
overall resilience and coping mechanisms to hazard impacts (International Strategy for Disaster Reduction, 2004).

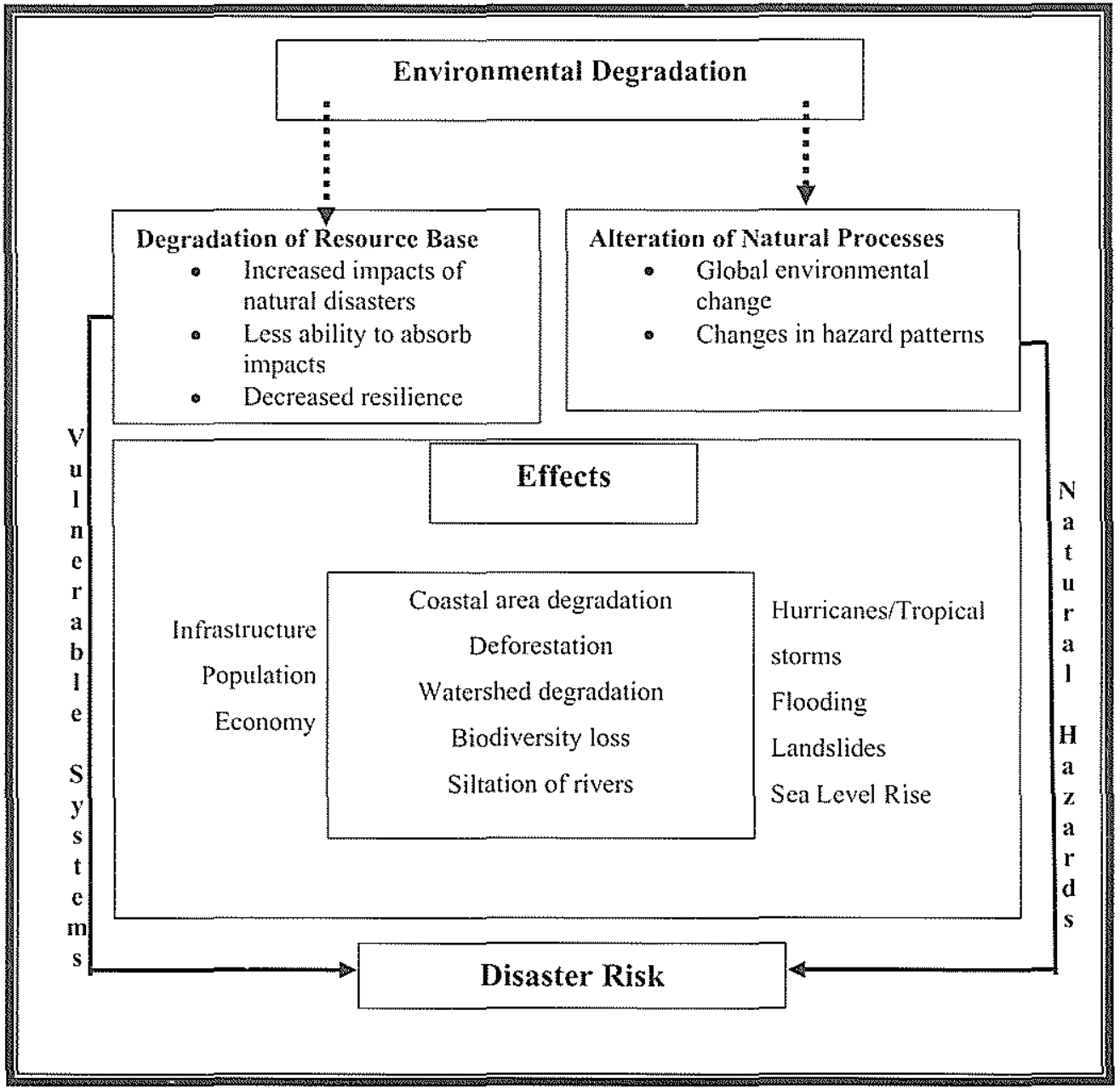

Figure 5: Relationship between Environmental Degradation, Natural Hazards and Vulnerability.

(Source: Adapted UN/ISDR, 2004)

\section{ENVIRONMENTAL PLANNING}

Over the years the Jamaican Government has embarked on a number of initiatives geared towards the proper management and conservation of the country's natural resources. The government recognizes that urban and rural 
planning must be done within the context of the wider thrust of environmental management, and to this end the government established the NEPA (DavisMattis, 2002). NEPA represents an amalgamation of the Natural Resources Conservation Authority (NRCA), mandated to ensure the proper management and use of the natural resources of Jamaica; the Town and Country Planning Authority is mandated to ensure the orderly development and planning of the country and the Land Development and Utilization Commission is mandated to ensure "that prime agricultural lands are kept in agricultural production in the interests of inter alia food security and self sustainability"(Davis-Mattis, 2002).

Table 1 summarizes the legal and policy framework for the conservation and sustainable use of resources in Jamaica. However, very few of these statutes according to NEPA and Ministry of Land and the Environment (2003:16), "deal comprehensively with the protection, conservation and sustainable use of biodiversity, as they are primarily sectoral in nature".

Table 1: Summary of the main Legislation/Policies aimed at the protection and management of natural resources.

(Source: Compiled by Author from various sources)

\begin{tabular}{|c|c|}
\hline Legislation/Policy & Summary of Instruments \\
\hline $\begin{array}{l}\text { Natural Resources Conservation } \\
\text { Act (1991) }\end{array}$ & $\begin{array}{l}\text { This Act provides for the management, } \\
\text { conservation, and protection of the } \\
\text { natural resources of Jamaica. }\end{array}$ \\
\hline The Beach Control Act, 1956 & $\begin{array}{l}\text { Ensures the proper management of } \\
\text { coastal and marine resources by a } \\
\text { system of licencing of activities on the } \\
\text { foreshore and the floor of the sea. It } \\
\text { also addresses issues such as access to } \\
\text { the shoreline. }\end{array}$ \\
\hline $\begin{array}{l}\text { The Forest Act (1995) and } \\
\text { Forestry Regulation (2000) }\end{array}$ & $\begin{array}{l}\text { Addresses the sustainable management } \\
\text { of forests. }\end{array}$ \\
\hline Endangered Species Act, 2000 & $\begin{array}{l}\text { Provides for the conservation, protection } \\
\text { and regulation of trade in endangered } \\
\text { species. A Scientific Authority is } \\
\text { appointed under the Act to determine } \\
\text { whether a species is at risk, vulnerable } \\
\text { or threatened. }\end{array}$ \\
\hline $\begin{array}{l}\text { The Natural Resources (Marine } \\
\text { Parks) Regulations (1992) }\end{array}$ & $\begin{array}{l}\text { The object of the regulations is the } \\
\text { establishment of marine protected } \\
\text { areas, primarily for the conservation of } \\
\text { marine resources. }\end{array}$ \\
\hline
\end{tabular}




\begin{tabular}{|l|l|} 
The Wildlife Protection Act & $\begin{array}{l}\text { Concerned with the protection of } \\
\text { specified species of fauna. }\end{array}$ \\
\hline $\begin{array}{l}\text { Coral Reef Protection and } \\
\text { Preservation Policy (1997), Draft }\end{array}$ & $\begin{array}{l}\text { Ensures the conservation of coral reefs } \\
\text { in order to sustain their ecological and } \\
\text { socio-economic functions. }\end{array}$ \\
\hline Watershed Protection Act (1963) & $\begin{array}{l}\text { Provide for the protection of } \\
\text { watersheds and areas adjoining } \\
\text { watersheds and promote the } \\
\text { conservation of water resources. }\end{array}$ \\
\hline The National Solid Waste & $\begin{array}{l}\text { Ensures effective management of solid } \\
\text { waste in order to safeguard public } \\
\text { health. }\end{array}$ \\
\hline The Wetlands Policy (Draft) & $\begin{array}{l}\text { Sets out a management strategy for the } \\
\text { protection of wetlands. }\end{array}$ \\
\hline Act (1957) & $\begin{array}{l}\text { The objective of this Act is to ensure } \\
\text { the orderly development of land. This } \\
\text { is achieved through Development } \\
\text { Orders which are the main means of } \\
\text { control of land use in Jamaica. }\end{array}$ \\
\hline National Land Policy & $\begin{array}{l}\text { Established for the proper planning, } \\
\text { management and development of the } \\
\text { use of land, recognizing the need to } \\
\text { balance land use management and } \\
\text { development with agriculture, mining, } \\
\text { tourism and natural resource } \\
\text { management. }\end{array}$ \\
\hline
\end{tabular}

Despite the various initiatives in the form of policies, legal instruments and institutional arrangements, sustainable urban development, holistic and integrated environmental planning and management remain elusive. It is therefore essential to explore the main reasons accounting for this shortcoming. Based on interviews with planners and other stakeholders in the planning process, this is a result of several factors which can be classified as:

a. Limited Compliance and Weak Enforcement

b. Policy and Institutional Overlap

c. Political and Governance Issues 


\section{a. Limited Compliance and Weak Enforcement}

This has been identified as the primary factor contributing to environmental degradation and development in hazard prone areas. The PIOJ (1997) pointed out that weak enforcement is as a result of inadequacy of funds, low technical capacity, and poorly developed capacities for operational and fiscal management. This situation is compounded by outdated development orders which have made it difficult to exercise effective control over development in the country. The issues that subsequently arose are the proliferation of unplanned settlements, destruction of natural resources and conflicting and nonconforming land uses. However, the Manager of the Planning Division at NEPA was of the opinion that even though the development orders are outdated, they still remain a useful instrument to guide development. This reasoning can be challenged by questioning how effective can a regulatory instrument be if it is archaic and unable to arrest the never ending cycle of the annihilation of the country's natural and coastal resources.

A related issue and concern is that the Environmental Impact Assessment (EIA) process has been criticized for not being comprehensive, especially with regards to tourism development. It is argued that EIAs have failed in many instances to address the full scale impact of tourism and other major developments in Jamaica. This process has been inadequate in several respects, notably, identification of the impacts on the terrestrial and marine vegetation, shoreline modification, inadequate monitoring of activities on construction site, limited time in which the public has to review ElAs and assessment of cumulative impacts, among others. This is seen as a major shortcoming and failure as the EIA decision making support tool forms the basis for mitigating and monitoring impacts in sensitive environments, argues Mycoo, 2006.

\section{b. Policy and Institutional Overlap}

Policy and institutional overlap is another over-arching challenge of achieving sustainable urban planning and management in Jamaica. There are several pieces of legislation, regulations and guidelines pertaining to the terrestrial environment, watersheds and the coastal zone. This has resulted in several lead agencies being responsible for similar functions leading to confusion and conflict, the waste of limited resources and perpetuation of environmental degradation. For instance, the Draft Watershed Policy noted that there is considerable overlap between six (6) agencies in authority over the handling of watershed areas and requires clarification. 
The legislation for the current planning system has resulted in duplication of functions, mainly in the development approval process, which is considered to be partially accountable for 75 per cent of development that takes place outside the formal planning system (Mchardy, 2002). These statistic highlight a high percentage of non-compliance to environmental and planning regulations which translate into the mushrooming of unplanned settlements and other illegal developments in environmentally sensitive and vulnerable areas, an appropriate example is the devastation in the Hope River Watershed in August, 2008.

\section{c. Political and Governance Issues}

Strong urban governance is critical to making progress but it is often the resource in short (Linden, 1996), and in the case of Jamaica, poor accountability of policymakers for their decisions, and failure to enforce envirommental laws and regulations is a manifestation of the challenges of poor governance and political issues. For instance, the continued expansion of planned and unplanned settlement in sensitive zones such as the Hope River Watershed has continued for years even in the face of mounting evidence of negative envirommental effects and high environmental costs. The academic literature asserted that the lack of political will to enforce regulations is because of fear of losing support from the electorate. Henry-Lee (2005) revealed that the significance about Garrison constituencies (is one in which electoral process is directly influenced by social and economic processes) in Jamaica is that there is a strong political capital. They become very important at election times. and the level of activity surrounding the politicians is remarkably high.

Even when there is a genuine attempt by the government to effect change. Jamaica's onerous debt burden is an obstacle that hinders the provision of the full range of investment in basic services, environmental management and disaster reduction strategies. The International Monetary Fund (IMF) reported that at the end of the fiscal year 2007/2008, the country's debt will reach over 1 trillion Jamaica dollars (Jamaica Gleaner, 2007), which has absorbed resources at the expense of economic and social investments. This has impeded the implementation, monitoring and review of plans and policies that are critical to the proper management and use of land resources in the country. In turn, many of these policies and strategies become difficult to implement and are relegated to the shelf.

This situation is heightened by the fact that until recently most development planning initiatives were specifically intended for economic benefits mostly to developers, with little or no regard to other critical concerns such as social and ecological sustainability (Henry and Heinke, 1996). This has 
been and is still manifesting in Jamaica in areas such as tourism and industrial development. The Tourism Expansion Programme is a prime example. An unreleased study commissioned by the Planning Institute of Jamaica (PIOJ), 2005 painted a grim picture of the current Tourism Expansion Project and its hotel development programmes. The study concluded that building more hotels will grow the economy and provide much valued short-term benefits for the country, but these benefits will not be sustainable at the proposed rate of development rationed for the Expansion Programme and there are risks if building does take place as proposed in certain environmentally-vulnerable areas (Jamaica Gleaner, 2006). Sango, 2007 argued that the heavily indebted governments of Third World countries are desperate for foreign currency revenue to an extent that they are prepared to risk allowing foreign investors and local industries to degrade the environment for as long as they satisfy the production targets desired by the state.

\section{RECOMMENDATIONS}

Changing urban development from its present unsustainable forms and patterns is a very challenging process (Kenworth, 2006). Notwithstanding that, if well managed, according to Cohen (2006), cities offer important opportunities for economic and social development. To realize the potential contribution of urbanization to sustainable development in Jamaica, a number of challenges have to be tackled in order to attain any measure of success. Issues such as poverty reduction, environmental degradation and governance failures must be pushed at the forefront of the policy agenda to reverse negative environmental trends and practices.

\section{i) Strengthen Legislative and Institutional Capacity}

Strengthening the legislative and planning machinery is a key step for mitigating the impacts of tourism and urbanization on environmentally fragile resources. Outdated development orders and environmental statutes should be revised and updated to transform current negative trends and practices. For example, even though Jamaica has a Watershed Protection Act which was passed in 1963, to date, no regulations have been promulgated for this act to come into effect, despite falling under the administration of NEPA and NRCA - the lead agencies mandated to protect the country's natural resources. This is a major shortcoming that has led to the continued degradation of the country's watershed areas. To cite another example, the St. James Development Order, dates back to 1982 and has not been revised or updated since despite the fact that Montego Bay is Jamaica's principal resort area.. An 
updated instrument(s) is therefore fundamental to guide the development process in a sustainable manner.

Bartone et al (1994) also recognized that institutional strengthening is a critical pre-requisite for improving urban environmental problems as well as reducing some of the challenges facing planners in the decision-making process. Such institutional strengthening is important to identify, understand and evaluate complex urban environmental issues that aggravate risk to natural hazards. Improved sectoral and inter-agency coordination is also an important element of institutional strengthening to resolve issues associated with fragmentation and institutional overlap in the decision-making process. Without adequate institutional capacity, plans are never effectively realized, nor can enforcement be properly executed. Moreover, strengthening of institutional capacity must be complemented by improved governance with greater transparency and accountability, as outlined in the United Nations Millennium Project, 2005.

\section{ii) Integrated Watershed Management}

Poorly managed activities in the watershed areas have led to their degradation which have in turn intensified flood hazard by increasing the quantity and velocity of run-off, increasing flood risk downstream, a manifestation of the detrimental effects of Tropical Storm Gustav, 2008. Added to the negative effects, the country's freshwater resource is also threatened. To this end, an integrated approach to watershed management involving all the relevant stakeholders is paramount. The Asian Disaster Preparedness Centre, 2005 defined integrated watershed management as a "multi-resource management planning process, involving all stakeholders within the watershed, who together as a group, cooperatively work towards identifying the watershed's resource issues and concerns as well as develops and implements a watershed plan with solutions that are environmentally, socially and economically sustainable".

It is evident that the adoption of an integrated watershed programme is needed to stem the impacts of human activities on watershed quality in Jamaica. As part of the watershed programme, a zero tolerance approach should be adopted to restrict and prevent inappropriate land use activities such as intensive agriculture and residential development in watersheds and floodplains in order to restore the integrity of the degraded watersheds. Additionally, coastal zone management should form part of the wider goals and objectives of the integrated watershed programme. 
An important part of such a programme will be monitoring the state of the watersheds and progress towards achieving specific objectives in order to identify gaps and revise strategies where necessary and track progress toward achieving the objectives. The application of Geographic Information System (GIS) can play a critical role in the watershed management programme by assessing watershed conditions through modeling impacts of human activities, on water quality and watershed restoration. The GIS tool would supplement better planning, decision-making, execution and monitoring of the watershed areas.

It should be noted, however, that the government has made several attempts to improve watershed management by the implementation of several projects such as the Trees for Tomorrow Project, a project focused on forest management and conservation, the USAID-GOJ Coastal Water Improvement Project and Ridge to Reef Watershed Project, for community-based projects aimed at improved practices in watersheds as well as outreach and enforcement, Despite these scattered successes, Bass and Geoghegan (2002) highlighted that constraints such as limited resources, an incomplete legal framework for watershed management and an uninformed citizenry are major challenges to overcome.

\section{iii) Incorporate Disaster Management in the Planning Process}

Incorporating disaster management in the overall planning process is a practical strategy which would take account of prevailing hazard risks and allow for the formulation of mitigation measures where development already exists and the discouragement of development where it has not yet taken place. Only by integrating hazard mitigation into all policies, programmes and plans at both the national and community levels can vulnerability be reduced and protect the environment. In addition, there needs to be more commitment to the kinds of research that can help fill data gaps and identify risk reduction policies.

\section{iv) Environmental Education and Public Awareness}

Public awareness and knowledge to overcome indifference to unsustainable land use practices as well as sensitizing the public on land management issues and the important role they can play in reducing environmental degradation is crucial. Central to the education programme must be to educate the public about the direct connection and domino effect of dumping solid and liquid waste in gullies, destruction of coral reefs and other coastal resources and degradation of watersheds because these activities decrease the resilience of natural ecosystems thereby increasing vulnerability to natural hazards. 
An informed citizenry may be "one of the most effective ways to move expeditiously toward environmental sustainability; while it is an insufficient condition for achieving environmental sustainability, without it, there is little hope that significant change will occur" (United Nations Millennium Project, 2005:70). Perhaps the strategy with the greatest long-term impact is to focus on the youngest generations in society. Environmental education based on life experiences should begin during the earliest years of life. These experiences play a critical role in shaping life-long attitudes, values and patterns of behavior toward natural environments (Tilbury, 1994).

\section{v) Political Commitment}

Political support and commitment is essential to the success of changing entrenched negative environmental practices in Jamaica that are draining national budgets and hampering all attempts of achieving sustainable development. The United Nations Development Program and Global Water Partnerships (2005) noted that political support and commitment is an important first step in creating awareness and drawing support to the process of environmental management. Unwavering political support is also needed to transform policies into action by ensuring the adoption and implementation of plans and commitment of government funds to effect change in Jamaica.

A high priority issue that requires strong political will and commitment is the alleviation of poverty as well as containing the mushrooming of squatter settlements, especially on marginal lands which perpetuate the cycle of urban environmental degradation and contribute to greater economic and environmental vulnerability. The government has made great strides to regularize and improve the lives of many squatters through the Operation Programme for Resettlement and Integrated Development Enterprise (PRIDE) programme; however, it failed because of charges of mismanagement and corruption. Henry-Lee (2005), from his research strongly argued that any strategy to eradicate poverty in the Garrison constituencies in Jamaica is subject to failure, as there are many people who have a vested interest in the perpetuation of poverty. The United Nations Development Programme Human Development Report, 1997 highlighted that "The poor can be politically convenient... They can also serve as a useful pool of voters for politicians who claim to serve their interests... Any strategy to eradicate poverty must therefore take into account the fact that many people have a vested interest in the perpetuation of poverty." A concerted effort is needed to change the political landscape of Jamaica, only then can sustainable development can be achieved. 


\section{CONCLUSION}

Managing urban growth has become one of the most important challenges of the 21 st century (Cohen, 2006). For Jamaica, managing urban growth along with associated environmental problems continues to be a daunting task hampering the effective management and protection of eco-systems and the services they provide. This has resulted in the degradation of the country's natural resources rendering the population, economy and infrastructure vulnerable to the effects of natural hazards. This is critical because environmental degradation increases vulnerability to the effects of natural hazards and reduce overall natural resilience, a prime example of the detrimental effects caused by Tropical Storm Gustav, 2008.

The proliferation of unplanned settlements on marginal lands, poor agricultural practices, mining, quarrying and deforestation have all led to the degradation of more than half of the country's watersheds as well as inadequate waste management are the visible symptoms of a city on the brink of destruction. Despite the evidence of attempts to improve environmental planning and management through legislative and policy framework and institutional reform, there are still shortcomings. Limited compliance and weak enforcement of regulations, policy and institutional overlap, political and governance issues are the major weaknesses that are hindering progress towards holistic environmental planning and management.

Moving towards sustainable development requires achieving economic and social systems which encourage environmental stewardship of resources for the long-term (Satterthwaite, 1999). As such, a clearer understanding of the interface of economic development and the environment is necessary if the problems are to be effectively gauged and resolved. Moreover, there needs to be better synergy between the effects of urbanization and environmental planning and management by addressing the root cause of the common problems. Critical to the transformation process must be legislative and institutional strengthening, integrated watershed management, incorporation of disaster management in the planning process, public awareness and education and strong political commitment. As aptly highlighted by the United Nations (UN) Millennium Declaration, we must "spare no effort to free all of humanity, and above all our children and grandchildren, from the threat of living on a planet irredeemably spoilt by human activities, and whose resources would no longer be sufficient for their needs." 


\section{REFERENCES:}

\section{Books/Journals:}

Ahmad, Rafi., 2005. Protecting Built Environment in a Natural Hazard Prone City: Kingston Jamaica. Unit of Disaster Studies, Department of Geography and Geology, University of the West Indies, Mona.

Asian Disaster Preparedness Centre and United Nations Development Programme., 2005. A Primer for Integrated Flood Risk Management in Asia.

Bartone, Carl, Janis. Bernstein, Josef Leitmann and Jochen Eigen., 1994.

Toward Environmental Strategies for Cities: Policy Considerations for

Urban Environmental Management in Developing Countries. Urban

Environment Programme, World Bank.

Cohen, B., 2006. Urbanization in Developing Countries: Current Trends, Future Projections, and Key Challenges for Sustainability. Technology in Society 28, pp. 63-80.

Croucher Herbert and Swabey, Christopher., 1937. Soil erosion and soil conservation in Jamaica. In Department of Science and Agriculture, Jamaica, Bulletin No. 17 (New Series). Kingston, Jamaica

Davis-Mattis, Laleta., 2005. Marine Debris: Jamaica's Response. United Nations Open Ended Informal Consultative Process on Oceans and the Law of the Sea. Sixth Meeting, New York 6-10 June, 2005. ., 2002. Jamaica's Commitment to the Conservation and Management of Natural Resources ten years in Retrospect. Unpublished Paper, National Environmental and Planning Agency; Kingston, Jamaica.

Drakakis-Smith, David., 2000. Third World Cities. Second Edition, London: Routledge.

Henry Glynn and Heinke, Gary., 2004. Environmental Science and Engineering. Second edition (GE $105 \mathrm{HEN}$ ).

Henry Lee, Aldrie., 2005. The Nature of Poverty in the Garrison Constituencies in Jamaica. Environment and Urbanization, Vol 17, No. 2, 83-99.

International Federation of Red Cross and Red Crescent Societies., 1999. World Disasters Report. Switzerland. pp. 19.

Kenworth, Jeffery., 2006. The Eco-city: ten key transport and planning dimensions for sustainable city development. Environment $\&$

Urbanization .Vol. 18 (1): pp. 67-85.

Leitmann Josef, Bartone, C., and Bernstein, J., 1992. Environmental Management and Urban Development: Issues and Options for Third World Cities. Environment and Urbanization, Vol. 4, No.2, pp. 131-140. Linden, Eugene., 1996. The Exploding Cities of the Developing World. Foreign Affairs 75 , No. 1:52-65. 
McHardy, Pauline., 2002. Urban and Regional Planning in Jamaica. Second Edition. Upfront Publishing: Leicestershire.

Ministry of Land and Environment., 2003. Jamaica National Assessment Report. A Ten Year Review of the Implementation of the 1994 Barbados Programme of Action for the Sustainable Development of Small Island Developing States.

Ministry of Local Government and Community Development., 2001. National Solid Waste Management Policy. Kingston, Government of Jamaica.

Mycoo, Michelle., 2006. Managing Land-based Space with Particular Reference to Traditional Uses/Poor. In Assessing Caribbean Sustainability Processes and Advocating Civil Society Strategies for Sustainable Development. Prepared by The Caribbean Sustainable Development Network.

National Environment Planning Agency, Natural Resources Conservation Authority and Ministry of Land and the Environment., 2003. National Strategy and Action Plan on Biological Diversity in Jamaica. Jamaica.

National Environment Planning Agency., 2001. Jamaica's Environment, 2001. Kingston, National Environment Planning Agency.

Environmental Action Plan. Status Report, 1999-2002.

1999. Jamaica National Planning Institute of Jamaica., 1997. Master Plan for Sustainable Tourism Development: Diagnostic and Strategic Options. Draft Report 1997.

Portes, Alejandro and Itzigsohn, Jose and Dore-Cabral, Carlos., 1993. Urbanization in the Caribbean Basin: Social Change during the Years of the Crisis. Working Paper. Johns Hopkins University. (Unpublished).

Rakodi, Carole. and Treloar, D., 1997. Urban Development and Coastal Zone Management: An International Review. Third World Planning Review. Vol. 19, pp. 427-481.

Satterthwaite, David (ed)., 1999. The Earthscan Reader in Sustainable Cities. Earthscan Publications, London.

Soil Conservation Division. 1944. First Annual Report. Department of Agriculture. Kingston, Jamaica.

Tilbury, Daniella., 1994. The critical learning years for environmental education. In. Ruth Wilson (ed.) Environmental Education at the Early Childhood Level. Washington D.C: North American Association for Environmental Education, pp. 11-13.

Tindigarukayo, Jimmy., 2006. Challenges in Housing the Poor in Jamaica: The Case of Squatters. A paper presented at the Conference on: Social Housing in the Caribbean. Organized by the National Housing Trust (NHT), Jamaica Conference Centre, June 19-20, 2006.

The Natural Resources Conservation Authority., 2003. Towards a National Strategy and Action Plan on Biological Diversity in Jamaica. 
United Nations., 2003. United Nations Demographic Yearbook. Washingston D.C.

United Nations Development Programme., 1997. Human Development Report. United Nations Development Programme, New York.

United Nations Development Programme and Global Water Partnerships., 2005. Integrated Water Resources Management Plans: Training Manual and Operational Guide. March, 2005.

United Nations/International Strategy for Disaster Reduction., 2004. Living with Risk. AGlobal Review of Disaster Reduction Initiatives.

United Nations Millennium Project., 2005. Environment and Human Wellbeing: A Practical Strategv. Task Force on Environmental Sustainability. Earthscan: London.

United Nations Office of Project Service., 1998. Planning and Environment of Heavily Contaminated Bays and Coastal Areas in the Wider Caribbean. Report.

Wakefield, A., 1941. Memorandum of agricultural development in Jamaica. The Government Printer, Kingston, Jamaica.

World Bank., 2000. World Bank Development Indicators 2000. Washington, D.C.

\section{Internet:}

Bass Steve and Tighe, Geoghegan., 2002. Incentives for Watershed Management in Jamaica: Results of a Brief Diagnostic. Caribbean Natural Resources Institute, Technical Report, No. 314. Available: $<$ www.canari.org/jamaicadiagnostic.pdf $>$.

Jamaica Gleaner., 2007. Debt Still the Big Issue. [On-line].[Cited 20 February 2008]. Available:

$<w w w . j a m a i c a-$

gleaner.com/gleaner/20070511/business>.

Jamaica Gleaner., 2006. Jamaica not ready for massive resort development. [online]. [cited 19 February 2008]. Available: <www.jamaicagleaner.com/gleaner/20060917/lead/lead5.html>.

Jamaica Gleaner., 2006. Tourism and development: Red Flags being Ignored. [online]. [cited 3 February 2008]. Available: $<w w w . j a m a i c a g l e a n e r . c o m / g l e a n e r / 20060924 /$ cleisure/cleisure2>

Jamaica Gleaner., 2003. Garbage a Major Concern. [online]. [cited 22 February 2008]. Available:

gleaner.com/gleaner/20030808/news/news4.html>

Neufville, Zadie., 2001. Fight to Save Long Mountain Continues. [On-line]. [Cited 20 September 2007].

Available:<website.lineone.net/ zadie/resume/longmts.htm>

Sango, I., 2007. Achieving the Millennium Development Goals in an Environmentally Sustainable Way- Some Perspectives for Relevant 
Zimbabwean Planners. Journal of sustainable Development in Africa. Volume 9, No.1.Fayetteville State University, North Carolina. [Online].[Cited 27 February 2007]. Available: $<$ www.jsdafrica.com/Jsda/Spring2007PDF/ARC_Archiving MillenniumDevGoals.pdf $>$

The Jamaica Observer., 2008. Misery and Misfortune in St. Andrew. [On-line]. [Cited 27September2007]. Available: <jamaicaobserver.com/news/html> United Nations Environment Programme Islands Website. Small Island Environmental Management. Unit B1, Problems in the Small Islands Environemnt. [On-line]. [Cited 16 August 2007]. Available: $<$ http://islands.unep.ch.siem.htm > 
